\title{
SMN1 wt Allele
}

National Cancer Institute

\section{Source}

National Cancer Institute. SMN1 wt Allele. NCI Thesaurus. Code C127864.

Human SMN1 wild-type allele is located in the vicinity of 5q13.2 and is approximately 29 $\mathrm{kb}$ in length. This allele, which encodes survival motor neuron protein, is involved in the modulation of spliceosome assembly. Mutation of the gene is associated with spinal muscular atrophy types 1 through 4. 